\section{(2) OPEN ACCESS}

\title{
The Judgment of the German Federal Constitutional Court regarding assisted suicide: a template for pluralistic states?
}

\author{
Urban Wiesing
}

\begin{abstract}
Correspondence to Professor Urban Wiesing, Institut für Ethik und Geschichte der Medizin, Eberhard Karls Universitat Tübingen, Tübingen, Baden-Württemberg, Germany; urban.wiesing@uni-tuebingen. de
\end{abstract}

Received 18 January 2021 Revised 26 April 2021 Accepted 4 May 2021
Check for updates

(C) Author(s) (or their employer(s)) 2021. Re-use permitted under CC BY-NC. No commercial re-use. See rights and permissions. Published by BMJ.

\begin{tabular}{|l|}
\hline To cite: Wiesing U. \\
J Med Ethics Epub ahead of \\
print: [please include Day \\
Month Year]. doi:10.1136/ \\
medethics-2021-107233 \\
\hline
\end{tabular}

\section{ABSTRACT}

The article presents the judgment of the German Federal Constitutional Court from 26 February 2020 on assisted suicide. The statements regarding human dignity, human rights and the relationship between citizens and the state are examined. Furthermore, the consequences resulting from this interpretation of human dignity for states that are pluralistic and based on human rights will be laid out. The court's judgment limits the power of parliaments and poses a challenge to many laws in states that see themselves as pluralistic, human rights-based states.

In February 2020, the highest German court, the Federal Constitutional Court, rendered a judgment on assisted suicide. It rejected a law from 2015 that prohibited 'business-like' assisted suicide as unconstitutional. The court decided unequivocally that the prohibition of assisted suicide services does not reconcile with fundamental rights and principles enshrined in the German constitution. The reactions were numerous. Some commentators considered the judgment 'historical', 1 deemed it 'the judgment of the century ' or 'revolutionary'. ${ }^{\text {,i }}$ The significance attributed to this judgment is not only due to liberalising assisted suicide in Germany but also because the relationship between citizen and state is determined by the highest judicial authority. In doing so, it invokes human dignity and the human rights derived from it. The decision raises further questions for Germany as to how assisted suicide should be regulated in practice. Furthermore, the interpretation of the relationship between citizen and state in the court's decision lead to further questions directed at pluralistic states based on human rights.

The judgment will be presented here, especially regarding its statements about human dignity, human rights and the relationship between citizens and the state. Also, the question will be posed which consequences result from this particular interpretation of human dignity.

${ }^{\mathrm{i}}$ translated; von Schirach $\mathrm{F}$ as cited in an interview. 'Eine Frage, die sich jeder Mensch stellen muss': Interview mit dem Autor Ferdinand von Schirach, dem Regisseur Lars Kraume, der ARDDegeto-Geschäftsführerin und Redakteurin Christiane Strobel und den Produzenten Oliver Berben und Heike Vößler. daserste.de [internet]. Nov 2020. https://www.daserste.de/unterhaltung/film/ gott-von-ferdinand-von-schirach/gott-ferdinandvon-schirach-interview-eine-frage-die-sich-jedermensch-stellen-muss-100.html (Accessed 29 Dec 2020).

${ }^{\text {ii }}$ translated; Kusch R, cited in M Keller, see ${ }^{1}$

\section{HISTORICAL BACKGROUND}

Assisted suicide was not regulated by law in Germany until 2015. Since 1871 suicide had not been illegal and, in turn, neither had respective assistance. Helping someone to commit suicide was only rarely done and physicians had a very repudiative stance towards the matter due to their professional ethos and regulations. However, two associations for assisted suicide had been established (Dignitas Germany, an affiliate of the Swiss association in 2005, and Sterbehilfe Deutschland in 2009), whose activities displeased conservative politicians, the medical associations and the Christian churches. So, these two organisations were meant to be prohibited by a new law. After extensive debates, the German federal parliament ('Bundestag') issued a law on 19 December 2015, adding $\mathbb{} 217$ to the German Criminal Code. ${ }^{\text {iii }}$ It allowed kin to assist towards suicide, but not persons who 'provided assisted suicide services (geschäftsmäßige Förderung der Selbsttötung)' (cf English version of the judgment at para. 3), that is, by providing, procuring or arranging the opportunity for a person to commit suicide as a professionalised service (judgment para. 9). The Bundestag considered the latter to be the case if such assistance was intended to be given repeatedly.

The associations for assisted suicide in Germany promptly ceased their activities but filed a constitutional complaint, joined by several physicians, and patients willing to end their lives, to the German Federal Constitutional Court. The court deliberated for a long time, held a public hearing in April 2019, and decided on 26 February 2020. The justices held that the prohibition of assisted suicide services is not compatible with human dignity as guaranteed by the constitution. ${ }^{2}$ The respective law was declared void. The detailed written reasoning given by the court shows that the justices not only deliberated on assisted suicide with great care but also expounded on fundamental issues that have far-reaching implications for human rights-based states.

\section{THE JUDGMENT}

When the President of the Federal Constitutional Court, Andreas Voßkuhle, said at the beginning of the public hearing in April 2019 that the case was not about giving a moral judgment on suicide, many were surprised at first-since, generally, assisted

\footnotetext{
iii See also original: \$217. Bundesamt für Justiz [internet]. https://www.gesetze-im-internet.de/ stgb/_217.html (Accessed 29 Dec 2020).
} 
suicide is considered a moral issue. But this comment points to the core position of the Constitutional Court: The highest court of a constitutional state cannot judge on morals. Rather, it is confined to ruling on the legality of measures, most importantly on whether a law or other interventions by the state, in this case $\$ 217$ of the German Criminal Code, breach the constitution or not. With this differentiation the court points out a clear separation of personal ethical conviction and state intervention.

The judgment is based on the following argument: In a pluralistic society, different ideas of a good life and a good death exist. It does not fall under the auspices of a human rights-based state to pass judgment on these ideas. Every person is allowed to conduct their life autonomously-and also end it on his or her own will. This view is derived from human dignity and each person's right of self-determination, the fundamental principles enshrined in the German constitution. Furthermore, the state may not prohibit the assistance towards suicide as it significantly impedes such a plan. However, this is what $\$ 217$ of the German Criminal Code did and is therefore not compatible with human dignity and human rights and, hence, void. The Federal Constitutional Court also noted that nobody may be forced to assist in suicide.

Even with such a clear ruling the respective statement of the court ought to be given detailed attention. The likely most crucial sentence of the court bears careful reading:

What is decisive is the will of the holder of fundamental rights, which eludes any appraisal on the basis of general values, religious precepts, societal norms for dealing with life and death, or considerations of objective rationality (No. $210^{\text {iv }}$; official English translation by the court)

It is easy to read from this sentence that the decision to end one's own life is inevitably without guidelines or arguments, by necessity always arbitrary. Religion, rationality, guiding principles and so on could add nothing to this. Some critics already were speaking of 'voluntaristic narrowing' in the judgment. ${ }^{3}$ But that is not the case. The court's statement pertains only to the state's authority to evaluate the decisions of its citizens. The state may not judge the will of the citizen, not even on the basis of the aforementioned criteria, but must accept it. However, this does not apply to the persons themselves or their communities of values or faith.

Of course, persons who are thinking about dying will draw on 'general values, religious precepts, societal norms for dealing with life and death or considerations of objective rationality' and certainly also further concerns. The decision to exit life is amenable to such considerations to a great degree. Yet citizens take these issues into account in different ways and attribute to them different weights so that their decisions are just as diverse. The Federal Constitutional Court now has ascertained that a state, based on human dignity and human rights, may not give preference to certain considerations in terms of content or result nor prohibit them. This is the crucial point of the judgment. Content-related considerations about dying have not lost any significance for the individual. But the state may not judge on

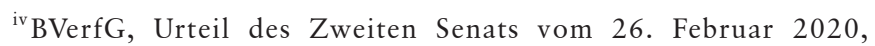
2 BvR 2347/15 -, No. 1-343. http://www.bverfg.de/e/ rs20200226_2bvr234715.html (accessed 29 Dec 2020). Official English translation by the Court available: https:/www.bundesverfassungsgericht.de/SharedDocs/Entscheidungen/EN/2020/02/ rs20200226 2bvr234715 en.html; jsessionid =5708 DF0A5BE77E5D9E899F79EAAB22161.2_cid377 (Accessed 29 Dec 2020).
}

the free decision of a citizen to live or die a certain way-of course under the condition that other citizens are not hindered in their way of life.

\section{DIGNITY AND AUTONOMY}

The judgment builds on a very specific interpretation of human dignity, human rights and especially the autonomy of a person. The discussion of these terms has a long history and fills entire libraries. Even if they are firmly anchored at the centre of the German constitution and play a big role in moral philosophy, it is still not clear even after far-reaching discussions what human dignity and autonomy may mean for suicide and assisting with it. The respective discourse has resulted in varied conclusions. ${ }^{4}$

Now the Federal Constitutional Court excluded the most restrictive interpretation of human dignity regarding state intervention in light of suicide: namely, that the autonomy of a human being may not lead to the destruction of the condition for potential dignity-biological life. While life is 'the fundamental basis of human dignity', it cannot be inferred that

committing suicide of one's own free will is contrary to human dignity guaranteed by Art. 1 (1) GG. [first article of the German constitution] [...] Thus, human dignity does not limit a person's selfdetermination, but rather is the very reason for self-determination: The person only remains an individual with personal responsibility, and thus a conscious subject, and their right to value and respect can only be upheld if they can determine their existence based on their own, self-defined standards ([...]).(No. 211 ${ }^{\mathrm{v}}$; official English translation by the court)

If a person evaluates autonomy 'based on their own, selfdefined standards' differently, say in the sense that it does not substantiate the legitimacy of suicide, this is indisputable and deserves protection. Whoever-whether alone or within a community of faith - wants to abide by a certain, substantiated idea of humanity and autonomy, may continue to do so. Only, and this is the decisive point of the judgment, the respective interpretation may not be prescribed to all other citizens. The Federal Constitutional Court excluded a specific, very narrow interpretation of autonomy and dignity regarding state regulations-not more. Therefore, no person is limited in her or his idea of a good dying process, rather only in the endeavour to make it a requirement for others and elevate it into law.

\section{NOT LIMITED TO ILL PEOPLE}

Germany's highest court does not limit the permission of assisted suicide to patients with terminal illnesses. The permission applies in all phases and situations of life, provided that a person is of age and capable of giving consent. This permission is broader than all the proposals discussed during the parliamentary debates about $\$ 217$ of the German Criminal Code in 2015. Even the liberal legislative proposal, that were not adopted in the end, included a limitation to serious illnesses. The court's rationale for this broad permission is important here:

The right to determine one's own life, which forms part of the innermost domain of an individual's self-determination, is in particular not limited to serious or incurable illness, nor does it apply only in certain stages of life or illness. Restricting the scope of protection to specific causes or motives would essentially amount

${ }^{\mathrm{v} B V e r f G}$, Urteil des Zweiten Senats vom 26, 2020. Available: http://www.bverfg.de/e/rs20200226_2bvr234715.html [Accessed 29 Dec 2020]. 
to an appraisal of the motives of the person seeking to end their own life, and thereby a substantive predetermination, which is alien to the Basic Law's notion of freedom. (No. $210^{5}$; official English translation by the court)

This is particularly interesting in light of the court considering an assessment as 'ill' or 'healthy' as 'situations defined by external causes'. To make the acceptance of the individual's will conditional on such a circumstance would be an inadmissible evaluation of said will. The individual must decide on their own, and their right to do so may not be limited by other peoples' evaluation or reasoning. A limitation of assisted suicide to certain life situations is not compatible with the liberty of the citizen.

\section{THE STATE AND ITS CITIZENS' MORALS}

This highly individualistic view has various implications for the responsibility of the legislative body. If freely exercising selfdetermination leads to changes in common moral consensus or majorities in a society, then the state must accept that.

However, preserving an existing or implied consensus on values and moral principles may not be a direct aim of criminal legislation [...]. A prohibition of assisted suicide services merely for the purpose of keeping the number of assisted suicides low is therefore impermissible; likewise, it is impermissible to pursue the aim of disapproving, placing under a taboo or framing as inferior in any other way the decision of a holder of fundamental rights, who acts of their own free will and in personal autonomy, to deliberately end their own life with the assistance of others. (No. 234 ${ }^{5}$; official English translation by the court)

Accordingly, potential cultural changes regarding dying and assisted suicide are not a sufficient reason for regulations by the state. If citizens choose a certain way of dying in a wellconsidered manner and on their own unimpeded will, the resulting social changes are to be accepted by the state.

These notions inevitably lead to an interpretation of a 'slippery slope' that weakens its argumentative force. The liberalisation of assisted suicide is argued against by pointing to the problem of some leeway leading to massive negative consequences that cannot be undone: Numbers would rise, assisted suicide would become a matter of course and this ought to be prevented. However, if the number of assisted suicides increased through the exercise of free self-determination and if a new social understanding emerged, this would not constitute a slippery slope according to the judgment of the Federal Constitutional Court, but the free exercise of given rights.

\section{THE PRICE OF INDIVIDUALISM}

The judgment emphasises the rights of an individual vis-à-vis the state. Nevertheless, it definitely does not endorse the concept of a purely individualistic state and opposes an individualistic understanding of human existence. On the contrary, it explicitly emphasises its relationality: 'self-determination is always understood to be relative'. (No. $235^{5}$; official English translation by the court).

The judgment thus assigns an important task to communities of values within a pluralistic society. For civil liberties pose challenges for many people. The question of what a good way of dying is remains for any person, even when the state may no longer weigh in on it. Everyone will have to find their own answer to this, unquestionably also drawing on religious or other values. Even if such conceptions cannot be made generally binding in a pluralistic society, they are relevant for individual persons. Communities of values can provide important orientation for individuals in this situation.

\section{SERIOUS, PERMANENT AND FOUNDED IN REALITY}

However, the Federal Constitutional Court has permitted the state to regulate assisted suicide, although in a limited way. The state is allowed to ascertain whether the decision of a person is serious, permanent, founded in reality and without external pressure. In this sense, state control does not extend to the substance of the autonomous decision, but to the protection of any such decision and the question of whether said decision is stable. Decisions that do not fulfil this condition must be excluded. Such is the case with an acute mental disorder (No. $241^{\mathrm{vi}}$ ) a temporary life-crisis (No. 244), or a sudden suicidal wish (No. 244). The decision must be founded in reality (No. 246) and be aligned with the person's own conception of self (No. 247). Furthermore, the state may set requirements for the providers of assistance and verify that there is no undue influence or pressure from third parties (No. 243).

A contradiction to the court's statements could be seen here, in that illness or health as externally defined conditions are not a sufficient reason not to accept an expression of will (No. 210). But the court speaks of 'acute' mental disorders and 'temporary' life-crises during which a will is not to be respected. For it is possible that a citizen regrets such a decision to commit suicide, should she or he survive it. Not the acute disorder or life-crisis per sé are a sufficient reason not to accept the will, but the lack of permanence and seriousness.

Moreover, the citizens' self-determination does not release the state from measures of suicide prevention. The court affirms that most suicide attempts are not made freely and responsibly, but rather are affective decisions that are largely regretted later on. The state must put up regulations against this. Nor does the judgment see any contradiction to efforts in palliative care:

Recognising the right to a self-determined death does not bar the legislator from taking general measures to prevent suicide. In particular, the legislator may take measures to expand and strengthen palliative care in order to counter wishes to commit suicide born out of illness. (No. $276^{5}$; official English translation by the court)

\section{REACTIONS TO THE JUDGMENT}

As expected, the ruling provoked controversial reactions. Many commentators criticised it from the point of view of a very specific ethical position. Because they morally reject assisted suicide, they rejected the judgment of the Federal Constitutional Court. It is precisely this reaction that fails to recognise the core point of the decision. For the court says nothing against a particular ethical position that rejects assisted suicide but confines itself to stating that the state may not make such an ethical position binding for everyone.

At its core, the judgment is based on the acceptance of plurality and on state neutrality vis-à-vis citizens' free decisions. But this is

\footnotetext{
${ }^{\text {vi }}$ All the following numbers indicate the paragraphs of the judicial statement regarding the ruling on assisted suicide from February 2020. To be found here in the German original: BVerfG, Urteil des Zweiten Senats vom 26. Februar 2020, 2 BvR 2347/15 -, No. 1-343, http://www.bverfg.de/e/rs20200226_2bvr234715.html (Accessed 29 Dec 2020).
} 
precisely the issue for those people and institutions who have a very clear notion of a good life and death and which they believe is so significant it must be made obligatory for others. The judgment is difficult to accept for those who cannot accept plurality.

This holds especially true for such institutions with clear conceptions about the right way to die: the Christian churches. They had advocated strongly for the criminal liability of assisted suicide. The judgment puts them in their place insofar as their notion of a good life and death are not granted any privilege by the law. This ought to be acceptable for them, as they can continue to take a clear position on assisted suicide for their members, but not mandate it for all citizens. However, the Christian churches, Catholic and Protestant, have firmly rejected the ruling in a joint statement. ${ }^{5}$ Hence, they demonstrate that they have not fathomed the ratio decidendi or that they reject the core message of the judgment and thus the makeup of a pluralistic society.

\section{WHAT DOES THE JUDGMENT MEAN FOR FURTHER REGULATION OF ASSISTED SUICIDE?}

Undoubtedly, assisted suicide is difficult to regulate and at risk of abuse. Premature suicides are known of and convincing arguments exist for avoiding them. And to determine the seriousness, permanence and foundation in realism in such situations is hardly easy.

In addition, commercial associations for assisted dying develop a vested interest. This could lead to undesirable consequences and to a subtle influence on a person's will. If this should not remain unregulated, the state must mandate procedural precautions by law. This—as the Federal Constitutional Court has emphasised-is perfectly in line with the German constitution. Smart regulations and detailed legislative work are required but must not relate to the actual substance of a citizen's free decision.

International precedents provide some experience for regulating assisted suicide. Other countries already have laws detailing how to check the seriousness and permanence of a wish to die and how to render the proceedings transparent. Furthermore, the permission of assisted suicide ought to be carefully documented regarding further developments and be accompanied by research. After all, an open society ought to be well-informed about assisted suicide, and correct regulations if necessary. All this is not excluded by the judgment of the Federal Constitutional Court.

The judgment did not mention killing on demand which is still prohibited in Germany. However, reading the judgment and the reasons why assistance towards suicide is permitted when a serious, stable and reality-based will is evident, the question arises why this is not applicable to killing on demand? A different legal regulation would have to be substantiated.

\section{THE MEDICAL PROFESSION AND ASSISTED SUICIDE}

The Medical Associations in the German Federal Republic, which have statutory powers, have always rejected physician-assisted suicide and prohibited it under binding professional codes. The court did not comment directly on medical professional law in its judgment. Nevertheless, the question arises what the judgment means for medical professional law. If a state may not prohibit assisted suicide, but at most regulate it, what then may the medical profession mandate for its members? It is not plausible that such official professional chambers or associations may prohibit something as a matter of their own regulation that the legislature may not prohibit. The fundamental tenets of the judgment also apply to professional codes inasmuch the fundamental principles enshrined in the German constitution establish a normativity from which professional associations cannot claim to be exempt. Insofar a ban on physician-assisted suicide by professional law would likely be unconstitutional. At best, a right of refusal for physicians to assist may be codified in the respective laws. Nobody can be forced to assist with suicide, this is also the case for physicians.

A directive by the medical associations regarding the respective conduct by physicians would be important. Doctors ought to have a role in assisted suicide, simply on considering the facts. No other profession can diagnose a treatable depression or recognise inadequate pain therapy better. No other profession can provide more adequate information about the options for medical treatment of an illness. Therefore, the involvement of physicians in assisted suicide is self-evident from a factual point of view.

\section{ASSISTED SUICIDE IN STATES BASED ON HUMAN RIGHTS}

The line of argument by the Federal Constitutional Court is by no means new in moral philosophy and political philosophy but has already been proposed frequently. Among others, Ronald Dworkin, Thomas Nagel, Robert Nozick, John Rawls, Judith Jarvis Thomson and Thomas Scanlon pointed in 1997 in a remarkable statement to the 'very general moral and constitutional principle-that every competent person has the right to make momentous personal decisions which invoke fundamental religious or philosophical convictions about life's value for himself' ${ }^{6}$

Now the highest German court has ruled in kind. Naturally, this has no ramifications for other countries, but it does throw up the question again what meaning human rights have regarding the relationship between the citizen's self-determination and the state. Other countries also invoke human rights as the basis for their core values, but with very different results regarding assisted suicide. ${ }^{5}$ Consensus about human rights does not lead to a consensus on assisted suicide. This will not change just as a result of the judgment. Now, however, a liberal interpretation of human rights has been explained in depth by a supreme court. Foremost, this interpretation limits the power of parliaments. According to this, they are prohibited from passing laws that 'pursue the aim of disapproving, placing under a taboo or framing as inferior in any other way the decision of a holder of fundamental rights, who acts of their own free will and in personal autonomy, to deliberately end their own life with the assistance of others' (No. 234 vii, official English translation by the court). Many parliaments of human rights-based states are unlikely to agree with this restriction at present.

The judgment has led to speechlessness on the part of German parliamentarians for a long time. It took 14 months for parliament to address the issue with a first 'orientation debate' on 21 April 2021.

Acknowledgements The author is grateful to Hans-Jörg Ehni, Danielle Norberg and Stefan Thomas for their helpful commentaries and linguistic support.

Contributors UW is the sole author of this paper.

Funding The authors have not declared a specific grant for this research from any funding agency in the public, commercial or not-for-profit sectors.

Competing interests None declared.

Patient consent for publication Not required.

Provenance and peer review Not commissioned; externally peer reviewed.

Data availability statement There are no data in this work.

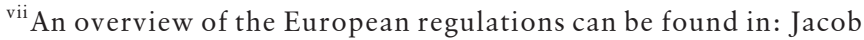
N. Sterbehilfe unter der Europäischen Menschenrechtskonvention (EMRK). Vorgänge - Zeitschrift für Bürgerrechte und Gesellschaftspolitik 2015:79-99.
} 
Open access This is an open access article distributed in accordance with the Creative Commons Attribution Non Commercial (CC BY-NC 4.0) license, which permits others to distribute, remix, adapt, build upon this work non-commercially, and license their derivative works on different terms, provided the original work is properly cited, appropriate credit is given, any changes made indicated, and the use is non-commercial. See: http://creativecommons.org/licenses/by-nc/4.0/.

\section{REFERENCES}

1 Keller M. Jeder hat das Recht auf Hilfe beim Suizid, egal, ob jung oder alt, gesund oder krank. zeit-online [internet], 2020. Available: https://www.zeit.de/2020/50/sterbehilfebundesverfassungsgericht-ethik-suizid-assistenz-krankheit [Accessed 29 Dec 2020]

2 Horn R. The right to a self-determined death as expression of the right to freedom of personal development: the German constitutional court takes a clear stand on assisted suicide. J Med Ethics 2020;46(6):416-7.
3 Schendel M. Die fragwürdige Autonomie von Karlsruhe. Zum Sterbehilfe-Urteil des Bundesverfassungsgerichts vom 26. Verfassungsblog: On matters constitutional 2020. doi:10.17176/20200306-214752-0

4 Macklin R. Dignity is a useless concept. BMJ 2003;327(7429):1419-20. doi:10.1136/ bmj.327.7429.1419

5 Marx R, Bedford-Strohm H. Gemeinsame Erklärung der Vorsitzenden der EKD und der Deutschen Bischofskonferenz zum Verbot der geschäftsmäßigen Förderung der Selbsttötung. EKD - Evangelische Kirche in Deutschland, 2020. Available: https://www. ekd.de/gemeinsame-erklaerung-dbk-und-ekd-zum-urteil-selbsttotung-53539.htm [Accessed 29 Dec 2020].

6 Dworkin R, Nagel T, Nozick R. Assisted Suicide: The Philosophers' Brief. New York Review of Books, 1997: 41-7. 